\title{
Synthesis and Crystal Structure of Mononuclear Complex of Pd(II) with Cyclic Thiourea
}

\author{
E. M. Nikandrov ${ }^{a}$, A. A. Grigor'eva ${ }^{b}$, A. V. Eremin ${ }^{a}$, \\ D. O. Ruzanov ${ }^{a}$, V. V. Gurzhii ${ }^{b}$, and A. N. Belyaev ${ }^{a}$ \\ ${ }^{a}$ St. Petersburg State Technological Institute (Technical University), Moskovskii pr. 26, St. Petersburg, 190013 Russia \\ e-mail:nikkiloid@gmail.com \\ ${ }^{b}$ St. Petersburg State University, St. Petersburg, Russia
}

Received April 6, 2015

Keywords: palladium, thiourea, square planar complex, crystal structure

DOI: $10.1134 / \mathrm{S} 1070363215080368$

Thiourea derivatives have been actively used in technology of rare and scattered elements, for example, as the specific ligands for isolation of the platinum group metals from the solutions of radioactive wastes [1]. The compounds are interesting in view of investigation of the processes leading to in vivo inactivation of cytostatic drugs in the course of therapy of oncological diseases [2].

Herein we report on synthesis and X-ray diffraction analysis of new mononuclear complex of palladium(II) with (4-thioxo-2,3,5,6-tetrahydro-1,3,5-triazin-1-yl) acetic acid (HL). The compound was prepared via Scheme 1.

The prepared complex crystallized in monoclinic crystal system with the space group $P 2_{1} / n$; the parameters of unit cell were as follows: $a=7.9745(4)$, $b=30.3509(19), c=12.2065(6) \AA, \beta=95.309(5)^{\circ}$, $V=2941.7(3) \AA^{3}, Z=4, R=5.6 \%$. According to XRD data, the complex consisted of mononuclear cation $[\operatorname{Pd}(\mathrm{LH})(\mathrm{L})(\text { bipy })]^{+}$, outer-sphere nitrate anion, and four solvating water molecules. Palladium atom was situated in the distorted square planar surrounding PdNNSS formed by a molecule of 2,2'-bipyridyl with two molecules of (4-thioxo-2,3,5,6-tetrahydro-1,3,5triazin-1-yl)acetic acid coordinated at the palladium atom through the sulfur atoms (Fig. 1). One of the ligands L contained a deprotonated carboxyl group.

Hydrogen bonding was revealed in the complex structure, involving both the inner-sphere molecules of the ligand and the outer-sphere molecules of water and nitrate anions (Fig. 2).

Complex $\left[\mathrm{Pd}(\mathrm{HL})(\mathrm{L})(\right.$ bipy) $] \mathrm{NO}_{3} \cdot \mathbf{4} \mathrm{H}_{2} \mathrm{O} .10 \mathrm{~mL}$ of a solution of $\mathrm{AgNO}_{3}(0.204 \mathrm{~g}, 1.2 \mathrm{mmol})$ was added to aqueous suspension of $\mathrm{Pd}(\mathrm{bipy}) \mathrm{Cl}_{2}(0.2 \mathrm{~g}, 0.6 \mathrm{mmol})$ acidified to $\mathrm{pH} 2-3$. The formed suspension was homogenized and incubated during $1 \mathrm{~h}$ at $60^{\circ} \mathrm{C}$. After

Scheme 1.

$\operatorname{Pd}($ bipy $) \mathrm{Cl}_{2} \underset{-\mathrm{AgCl}}{\stackrel{\mathrm{AgNO}_{3}, \mathrm{H}^{+}}{\longrightarrow}}\left[\operatorname{Pd}(\text { bipy })\left(\mathrm{H}_{2} \mathrm{O}\right)_{2}\right]^{2+} \stackrel{\mathrm{HL}}{\longrightarrow}$

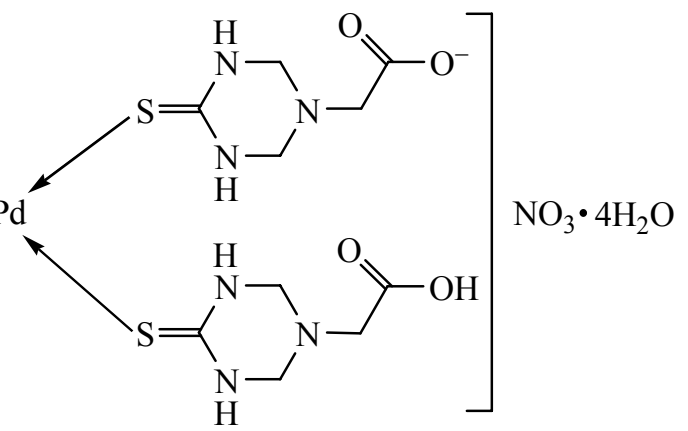




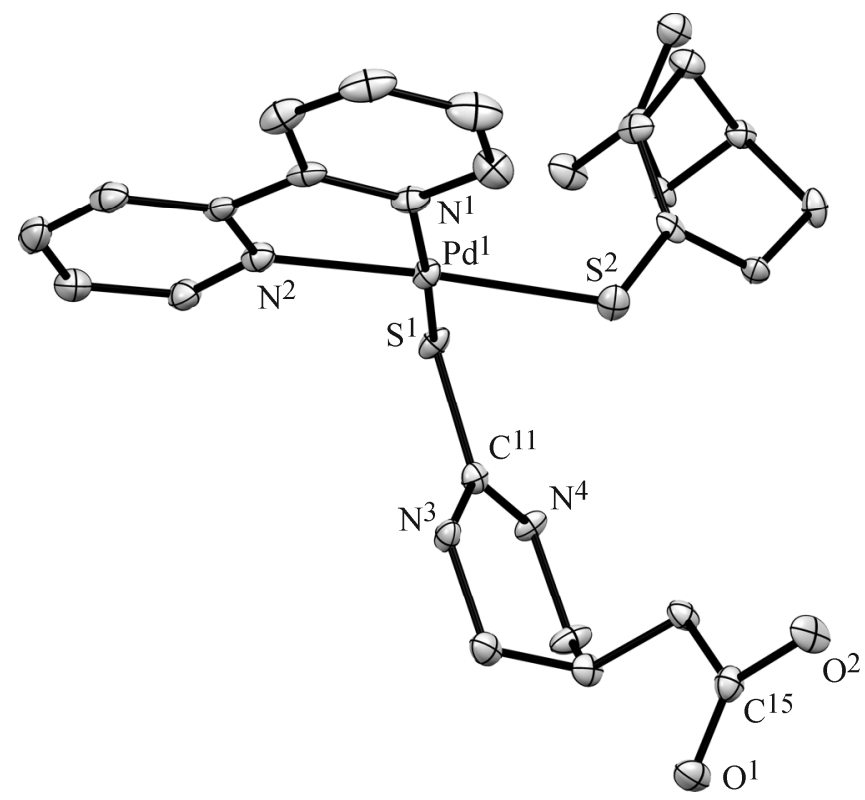

Fig. 1. Structure of the complex cation (thermal ellipsoids at $50 \%$ probability level; hydrogen atoms are omitted).

removal of precipitated $\mathrm{AgCl}$, a solution of (4-thioxo2,3,5,6-tetrahydro-1,3,5-triazin-1-yl)acetic acid $(0.210 \mathrm{~g}, 1.2 \mathrm{mmol})$ in a $\mathrm{H}_{2} \mathrm{O}-\mathrm{CH}_{3} \mathrm{CN}$ mixture $(1: 1$, $\mathrm{v} / \mathrm{v})$ was added to the filtrate. Next day, the formed precipitate was separated, washed with cold water and with acetonitrile, and dried. Yield 35\% (with respect to the metal). IR spectrum, $v, \mathrm{~cm}^{-1}: 3406(\mathrm{OH}), 3094$ $(\mathrm{NH}), 2919,1727(\mathrm{C}=\mathrm{O}), 1593,1581\left(\mathrm{C}-\mathrm{N}, \delta_{\mathrm{NH}}\right)$, 1531, 1382, 1333, 1309, 1302, 778, 726. Found, \%: C 31.78; H 4.85; N 16.15; O 24.01; Pd 14.80; S 8.37. $\mathrm{C}_{20} \mathrm{H}_{33} \mathrm{~N}_{9} \mathrm{O}_{11} \mathrm{PdS}_{2}$. Calculated, \%: C 32.19; $\mathrm{H} 4.45 ; \mathrm{N}$ 16.89; O 23.58; Pd 14.26; S 8.59.

IR spectrum $(\mathrm{KBr})$ was registered at $5000-400 \mathrm{~cm}^{-1}$ using an Infraspek FSM-1202 Fourier spectrometer. Single crystal X-ray diffraction analysis was performed using an automated Bruker Smart APEX II $\mathrm{CCD}$ diffractometer $\left(\mathrm{Mo} K_{\alpha}\right.$ radiation, $\lambda=0.71073 \AA$, graphite monochromator).

Dichloro(2,2'-bipyridyl)palladium(II) was synthesized via a method adopted from [3]. (4-Thioxo2,3,5,6-tetrahydro-1,3,5-triazin-1-yl)acetic acid was prepared via the known method [4]. 2,2'-Bipyridyl and

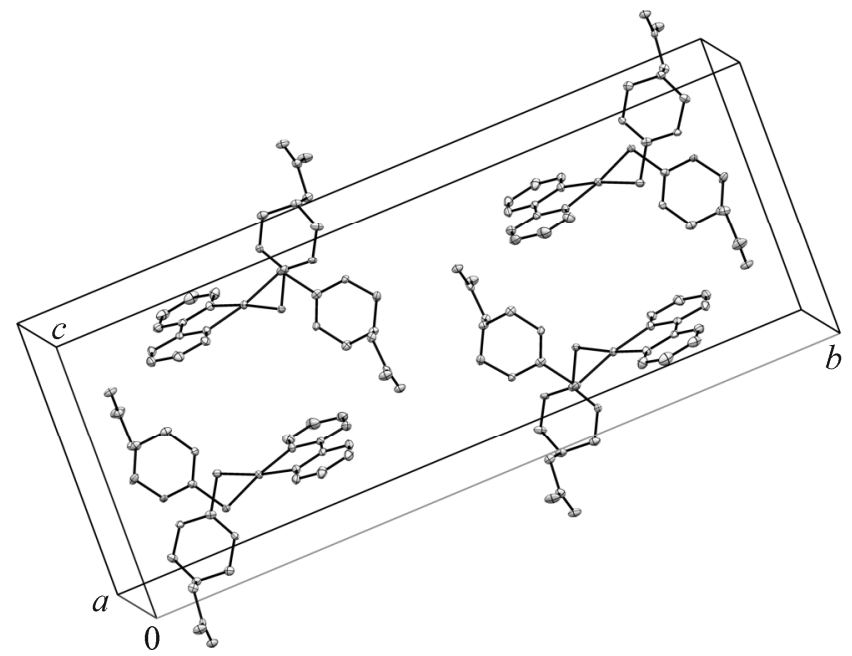

Fig. 2. Crystal packing in the molecule of complex $\left[\mathrm{Pd}(\mathrm{HL})(\mathrm{L})(\right.$ bipy) $] \mathrm{NO}_{3} \cdot 4 \mathrm{H}_{2} \mathrm{O}$ (solvating molecules of water, outer-sphere nitrate cations, and hydrogen atoms are omitted).

silver(I) nitrate (both of "analytical pure" grade) were purchased from NevaReaktiv and used as received.

X-Ray diffraction analysis was performed at the Resource Center "X-ray diffraction methods of investigations" of St. Petersburg State University. The XRD data were deposited at the Cambridge Structural Database (CCDC 1014158).

\section{REFERENCES}

1. Parajuli, D., Hirota, K., and Seko, N., J. Radioanal. Nucl. Chem., 2011, vol. 288, p. 53. DOI: 10.1007/ s10967-010-0870-4.

2. Shoukrya, M.M., Hassounab, M.M., and Mahmoud, R.K., C. R. Chimie, 2012, vol. 15, p. 356. DOI: $10.1016 /$ j.crci.2011. 12.003.

3. Sintez kompleksnykh soedinenii platinovykh metallov (Synthesis of the Complexes of Platinum Metals), Chernyaev, I.I., Ed., Moscow: Nauka, 1964.

4. Song, Minyan, Ramsh, S.M., Fundamensky, V.S., Solov'eva, S.Yu., and Zakharov, V.I., Russ. J. Gen. Chem., 2012, vol. 82, no. 2, p. 236. DOI: 10.1134/ S1070363212020132. 